\title{
Medical negligence: An insight
}

\author{
Shrestha $\mathbf{R}$ \\ Intern Doctor, Kathmandu Medical College, Sinamangal, Nepal
}

$\mathrm{M}$ edical Negligence is a subject of interest not only in Nepal but in the whole world. "More Americans die as a result of medical errors made in hospitals than as a result of injuries from automobile accidents" concluded a report published by Institute Of Medicine, New York ${ }^{1,2}$. What does this imply? Shouldn't we be concerned about the strain it will bring to the doctor - patient relationship? Shouldn't we be concerned about the image of the medics it portrays? Definitely, we should.

One news made headlines in 1992 when a 17 year old girl died at Duke University medical center after heart lung transplantation. It would not have made so much of news had she died of failure of the procedure. But she died just because of the mere inability of the physicians to see that the donor's and the recipient's blood group didn't simply match ${ }^{3}$.

This is an example of commission of an act that caused harm or loss to the patient - the general and prevailing concept of medical negligence among all. But, what most people easily forget is that medical negligence also includes an act of omission - failing to do what is required in order to prevent the harm that occurred to the patient.

\section{Causes of medical errors}

In one study, doctors stated the understaffing of nurses, overwork, stress or fatigue as the major causes of medical errors. The public pointed out physicians not having enough time, over work, stress, failure of health professionals to work as a team and understaffing of nurses as major causes of medical errors ${ }^{4}$.

Over work, lack of coordination and communication among the co-workers, insufficient time spent by the doctors with their patients etc compromise patient care. There is more in the list as well and there is no doubt. But everyone has to agree that it's not always the doctor who is responsible for the adverse outcome. There are many people involved in the treatment of a patient that a mistake can occur from any body's side. A doctor can't simply help himself if the pathologist gives him a wrong report or the sterilizing unit gives him unsterile equipments.
Besides, many times it is the patient himself who is responsible for any wrong that happens to him. What if the patient didn't take the medicines at time, what if he took another medicine instead?

\section{To tell the patients of the mistake or not?}

Medical ethics tells a doctor to explain everything to the patient. But then, is it as easy as it's said? You never know how the patient is going to respond. The patient might seek legal action and with the media so pervasive these days, there is fair chances that you might appear on the front page of every daily papers the next morning. These dangers definitely make ethical medical practice intimidating. But, things might not be as bad as they seem. A study interviewed 407 patients on how they would react to medical errors and disclosure ${ }^{5}$. The study concluded that non disclosure increased legal complaints and patient dissatisfaction. So, it seems a good idea to disclose errors to the patient. But the outcome depends on how you do it. Here comes the importance of proper counseling capability. It is a very essential skill every physician has to master.

\section{How do patients respond?}

It's an overstatement to expect patients to not feel bad about the harm that befell them. Besides the anger and dissatisfaction in the face of patients, we often fail to notice other emotions. Tom Delbanco and Sigall K Bell wrote that even when patients suspected mistakes were being made, many feared that confronting medical staff might lead to further injury ${ }^{6}$. Similarly, the family members often feel guilty for not having protected their loved ones from the care giver's mistake or not taking their loved ones to a better doctor.

Amidst all the overwhelming emotions of the patient, doctor's feelings do often get overlooked. No body bothers to think - how the doctor feels about the incident? Naturally, they don't have good time either. Clinicians too suffer alone, agonizing over the harm they have caused, the loss of their patient's trust, the

\footnotetext{
Correspondence

Dr. Resha Shrestha

Intern doctor

Kathmandu Medical College, Sinamangal, Nepal

E-mail: resha shrestha@hotmail.com
} 
loss of their colleague's respect, their diminished self confidence and the potential hazards to their careers. Besides, there always remains a big fear of legal actions against the error.

\section{Current scenario}

Many times, errors occur due to doctors' fault and they deserve punishment and the patients - compensation. There is no doubt and argument over it. But are things as clean as they seem? Definitely not! There is no lack of instances when doctors have been trapped and made to pay huge compensations for errors which in fact have not happened or even if have happened, are not due to the faults of doctors. Many times the malpractice suits do not involve malpractice at all. I would like to refer to a case in Nepal - where a surgeon was accused of killing a patient, who in fact died of a surgical complication, which could no way be attributed to the surgeon's acts. The doctor had to go through intense mental torture and had to pay hefty amount of money as well?

But that's not all. More disheartening is the fact that, more money is spent fighting the case than compensating the injured. A report said - for every dollar spent on compensation, 54 cents goes for administrative expenses (including expense involving lawyer, experts and courts $)^{8}$. So, it would have promoted patient health care if all compensation went to the patient but it's just not how things go.

Under such environment, medical work insurance seems a way out. Due to increasing lawsuits against adverse medical outcome, many doctors feel it safe to get themselves insured. This is supposed to relieve them of constant fear of unnecessary legal problems. But, this too may not help them anymore. The insurance cost has escalated so much that most doctors can now hardly afford them. However, the Ministry of Health in Nepal is considering of enacting legislation of this sort for doctors here.

The end result is - doctors become alert of every action they take. They focus more on how to stay safe legally rather than to care for the patient. Before doing any procedure, they'd rather get a consent paper signed first. This, undoubtedly, compromises the immediate and quality health care every patient deserves.

\section{The solution}

\section{Practicing Evidence Based Medicine ${ }^{9}$}

The trustworthiness of clinical guidelines depends on marshalling and interpreting best evidence, which is usually of variable quality and credibility. Evidence based standards will almost always be defensible, although some US courts have indicated that slavish compliance with evidence based guidance could be considered substandard, where patients are foreseeably harmed as a consequence. Guidelines do not actually set legal standards for clinical care, but they provide the courts with a benchmark by which to judge clinical conduct.

\section{Prevention of medical errors}

Preventing medical errors altogether is impossible. The realistic goal would be to reduce its incidence. Strict rules and regulation should be there to check and keep clinicians aware of their patients and to avoid any negligence. The patients should also help the doctors to achieve better health care. They should properly follow the instructions and more than anything should support the decisions of the doctors.

\section{Proper communication skills}

Proper counseling and communication creates a cordial environment where medical errors are less probable. Even at adverse situations, communication skills help because it all depends on how you break the news!

\section{References}

1. Kohn LT, Corrigan JM, Donaldson MS, eds. To err is human: building a safer health system. Washington, D.C.: National Academy Press, 2000 .

2. Leape LL. Institute of Medicine medical error figures are not exaggerated. JAMA 2000;284:95-7.

3. Edward WC. A death at Duke. N Eng J Med 2003 Mar 30;348(12):1083-4.

4. Blendon RJ, Desroches CM, Brodie M, Benson $\mathrm{JM}$, Rosen AB, Schneider E et al. Views of practicing physicians and the public on medical errors. N Eng J Med 2002 Dec 12;347(24):193340.

5. Mazor KM, Reed GW, Yood RA, Fischer MA, Baril J, Gurwitz JH. Disclosure of medical errors what factors influence how patients respond? J Gen Intern Med 2006;21:704-10.

6. Delbanco T, Bell SK. Guilty, afraid and alone - struggling with medical error. N Eng J Med 2007 Oct 25;357(17):1682-3.

7. The Nepali Times. Nursing home vandalized. Kathmandu: Himalmedia private limited; [updated 2008 May 24; cited 2008 September 8]. Available from: http://www.nepalitimes. com.np/

8. Studdert DM, Mello MM, Gawande AA, Gandhi TK, Kachalia A, Yoon C, et al. Claims, Errors and Compensation Payments in medical malpractice litigation. N Eng J Med 2006 May 11;354(19):2024-33.

9. Hurwitz B. How determinations of medical negligence? BMJ 2004;329;1024-8. 